\title{
Current Mining Taxation Policy Implemented by both Mongolia and Kazakhstan: The Development Comparatives between Ulaanbaatar and Astana
}

\author{
Antony D. Miller
}

$\mathrm{PhD}$ in Educational Leadership; International Educational Advisor for Santis Educational Services: Economics, Political Science \& Educational Leadership Fellow to The Chartered College of Teaching, UK

\begin{abstract}
This paper's purpose is an attempt to examine the taxation policies enacted onto international mining companies operating in both Mongolia and Kazakhstan (being geographic neighbours) and both nations have a similarity within their respective extraction of raw minerals and other precious metals/resources therein. In addition, this body of research will display a succinct deviation in one country's corporation tax policy compared to the other; how it has created the "phoenix from the ashes" scenario between Astana-Kazakhstan and the meagre resourced outcome for development in Ulaanbaatar-Mongolia. The data will also illustrate how a nation's gathering of revenue, has been undermined due to the pressure from international mining companies, which are indeed supported by foreign entities. Therefore, highlighting the differences in policy in corporation taxation within two neighbouring administrations. This report will objectively compare mining extraction quantities and projected revenues concurrently via confirmed cited testimonials from official governmental respected offices of statistics inclusive of the contributions from notable audit firms involved with the data collection cum archiving. The data therein would confirm this paper's findings within empirical validity via Standard Error projections within the subject matter's hypothesis and subsequently determine data mining findings.
\end{abstract}

Keywords: mining, taxation, globalization, policy, revenue, multinationals, \& minerals.

JEL Classification: L72, H2, F6.

Cite as: Miller, A.D. (2019). Current Mining Taxation Policy Implemented by both Mongolia and Kazakhstan: The Development Comparatives between Ulaanbaatar and Astana. Business Ethics and Leadership, 3(2), 3952. http://doi.org/10.21272/bel.3(2).39-52.2019.

(C) The Author, 2019. This article is published with open access at Sumy State University.

\section{Introduction}

Having both observed the under-development and sparse resources Mongolia's capital city Ulaanbaatar has to offer currently, we must consider the causation factors involved, from both a fiscal perspective as well as its a social consideration. This paper will try to exemplify pre-causes and their effects on a developing nation's capital city, which is the coldest legislative base on the planet.

A nation's tax revenue is defined as monies collected in form of taxes on income and profits, social security contributions, levied on goods and services, payroll taxation on the ownership and transfer on the property, and all other monies that denote taxation to be levied.

This paper will attempt, therefore, to describe its findings in a country-by-country analysis where taxation policy of two states, where only one would succeed in a rebirth of a city, the other would show a failure to illustrate any signs of improvement inclusive of its pollution crisis. We are all aware that developing states could either grow or fail to germinate societally if their respective tax-planning stratagem were to be influenced by an external banking entity. Furthermore, Neoliberal viewpoints or paradoxical hypothesis, are merely devised for a pre-envisioned globalist-debt controlled nation's agenda; yet, act accordingly with this mantra. Consequently, this paper will display via credible tabulated sources the "pre-envisioned debt control of a nation" concept and how it has affected one of the said nation states alluded in this body of research. We also must recall "Corruptissima re publica plurimae leges ad": the more corrupt the state, the more numerous the laws (Tacitus, AD c.55-c.117). This paper will also show the results or lack of quantitative investment on a city's infrastructure due to inefficient or dispositive taxation policy laws levied upon multinational companies i.e. MET (Mining Export Tax) and other legitimate sources inclusive of Mining Products with sales taxes levied. We will see the contrasting issues of these two developing nations and how one of these (Mongolia) 
ISSN (online) - 2520-6311; ISSN (print) - 2520-6761

has been subverted via external banking entities to legitimize their hold over a nation's sovereignty. It must be noted that there is interference from another NGO of whom is pushing a globalist agenda to internationalize Kazakhstan's Mining Extraction Tax Agenda. "The new legislation re-affirms Kazakhstan's commitment to transparency reporting through Kazakhstan's adherence to the international Extractive Industries Transparency Initiative (EITI) standards, imposing reporting requirements on payments from the sector to all relevant authorities. Despite this progress, important challenges remain to be addressed, particularly in the areas of taxation and oversight. With regards to mining taxation, which is handled separately as part of the Tax Code, the use of mineral reserves as a tax base, as opposed to the more common sales/profit-based mechanism will continue to be a concern for operators, given the potential risk of liability for tax payments irrespective of the commercial viability of reserves at any given moment" (OECD, 2018). The aforementioned proposal to Kazakhstan's Mining Sovereignty is more a measured threat of globalist control rather than introducing this nation into the international club of world mining. This is still a developing country, moreover, developing its own economic infrastructure within its own demography. The companies cited in this paper are Turquoise Hill, Rio Tinto (now merged) and Oyu Tolgoi of Mongolia.

\section{Literature Review}

Initially, since arriving in Mongolia in 2017, it was observed by both visitors and the local populous that there was a succinct impression that the nation had made great strides to privatization, notably within the mining sector. Overseas mining companies had been investing heavily in the Southern region of the Gobi Desert, and employment was indeed plentiful. Objectively, the question had to be asked; Why has there been a lack of fundamental development within the country, nor an increase in salary conditions related to GDP?

To retain one's objectivity within this body of research, a synthesis of all correlated data from Mongolia, had to be in comparison to another nation of which is similar in demography, geographical location and of identical underground natural resource (Commodities). Even more fortunate for empirical accuracy, Kazakhstan has both near identical resources as well as two international mining entities that both extract materials and therefore have operational investments in both Mongolia and Kazakhstan.

Since Mongolia's democratization in 1990, the strides Mongolia had made strides within a free market economy. This transition was turned this nation into a model for the whole region. As stated in a report From Mineral Riches to a Sustainable Future Trankmann, B. (2018) it details how the nation's Millennium Development Goals had removed half a million of its citizens from poverty. The publication also mentioned that the Gobi had undiscovered plentiful mineral wealth. Also notated within the overall economic predictions was that additional mining employment would increase into the thousands as Rio Tinto (UK-AUS) and the government-owned Oyu Tolgoi were to move into the final phases of development; hence boosting Mongolia's overall economy inclusive of increasing the construction sector.

Previously, Mongolia was very distinctive it had and, in some cases, has insider and outsider ownership. The administration was and still is assigned to either the central or local governments, hence the ambiguity this was according to Anderson, J. H., Lee, Y. and Murrell, P. (2000). Within the same document the authors described in detail both the negatives and the positive implications of this neoliberal policy being adopted in Mongolia. The paper cited entitled "Competition and Privatization amidst Weak Institutions: Evidence from Mongolia, Economic Inquiry" 38. p. 536 illustrated that State ownership had remained fixed before privatization. This was a variable measurement device whereby state ownership measures the proportion of enterprise that has been owned by the state itself. Mongolia's histology was part of the thesis for this study to be initiated.

A further question to be asked is a simple one; How does a country with such an abundance of wealth and future prospects fiscally, has a capital city (Ulaanbaatar) that is famed for being the coldest climatically in the world, and more infamously, has the most dangerous toxic pollution on the global index?

Comparatively, Astana (Kazakhstan) a young city of 20 years of being reborn, has been transformed into a mega city, so futuristic due to the revenue received from its mining operations apart from its LPG and Crude Oil reserves. One would notice how one capital city of similar resources compare with another i.e. Developed and the other Underdeveloped in such a vast way. In relation to this enduring research, a model of comparatives was established to ascertain how mineral wealth had been dispersed throughout these two sample mining nations so close in geographical proximity. This was the basis of this body of research and intense analysis thereof. As depicted in an article via the Business Inside Singapore; it clearly describes how Astana grew from a former gulag-type prison camp into a metropolis in a few years (Abadi, M., 2018). 
Revisiting the Mongolian Mining fabric once more, it is copiously stated in a further editorial by Reuters that it had made several references to another report. Bridge, G. (2004), Mapping the Bonanza: Geographies of Mining Investment in an Era of Neoliberal Reform, The Professional Geographer (vol. 56). It referred that this era of reformation is not a clear indication that Mongolian prosperity could indeed be sustained. Furthermore, Deutsch, A. and Edwards, T. (2013), Special Report: In Tax Case, Mongolia is the Mouse that Roared. cites anecdotal reforms and measures via both globalization and neo-liberalism since the 1990s especially within developing countries which are new to capitalism had indeed expanded so quickly within globalization that it has resulted in an unclear prognosis for Mongolia's future fiscal outlook. These previous paragraphs had presented the research with the uncertainties and subsequent material to delve into the depths of operational, revenue gathering and financial policy decisions made within both of the exchequers, moreover, to paint an empirical framed hypothesis to view why has in-country development is so vast in disparity? Upon the release of disturbing news alleging unscrupulous practices in the Mongolian Mining Industry Re: Munkhchimeg, D. and Lewis, B. (2019), Reuters. Mongolia, "Overseas investigators probe Oyu Tolgoi corruption claims as exminister re-arrested".

When this article eluded to Mongolia is working with overseas investigators to look into claims of corruption at its Oyu Tolgoi copper mine (one of the world's largest) and other indications of abusing power, then the premise for this paper was established. Objectively, there was sufficient room to explore what is actually occurring in Mongolia's neo-liberal model of expansion compared to how the Kazakhs had developed its own capital city and interior infrastructure, as Ulaanbaatar had and has not seen any form of major structural improvement inclusive of the population's financial wellbeing. Could the reports be correct within Mongolia's Ministerial Corruption Findings, or was it mere politics? As the article suggested, there had been ambiguity. "The mine, run by Rio Tinto since 2010, is central to the firm's push to reduce its reliance on iron ore sales. But the miner has faced a series of wrangles with the Mongolian government over tax payments and cost overruns..." So, a former finance minister was among the signatories to the investment agreement, approved by Mongolia's parliament. We will see how this case progresses? However, in the meantime data has been collected via the aforementioned sources to try to both mathematically prove in the realms of economics and public policy, to gather sufficient conclusions. Both nation's taxation decisions to-date, and their implementations were looked into to establish if there was a profound error within certain policies in corporate taxation, and what had been achieved in going from profit to develop a nation further domestically or to witness an unchangeable increase in a country's living standards? The paragraphs below display how the data was sourced:

Firstly, both nation's corporation tax levies had to be investigated, this was via the assistance from the audit firm Deloitte, (2018) Introduction of the New Tax Code. Report for Kazakhstan. This was the official data recorded from the Finance Ministry of Kazakhstan, which was a logical platform for analytical commencement.

Secondly, the retention of updated accuracy was accomplished with the data gathered in assistance from the ongoing publications within the Mongolian government the statistics which were provided by Kiezebrink, V. et al. (2018), Mining taxes, "The case of Oyu Tolgoi and profitable tax avoidance by Rio Tinto in Mongolia" SOMO Mining taxes, "The case of Oyu Tolgoi and profitable tax avoidance by Rio Tinto in Mongolia" these had aligned the data symmetrically as a synthesis to proceed to the comparative phases of this paper thorough attributing standard error of the difference calculations. To confirm certain volumes of production and to preselect the 12 commodities required for this comparative study, the previously cited paper was very useful for year-on-year bi-lateral comparisons, thus referencing for up-to-date mining production volumes correlated with the market price.

Thirdly, all commodity prices had to be factored-in on the very same day Re: 05/Apr/2018 these up to the minute prices were conveyed via two reliable sources: Export.gov. (2017), Mongolia-Mining and the second data source was: Index Mundi, (2018), Commodity prices. These data miners retained the accuracy of the data within statistical analysis models and charted conveying tabulated comparatives inclusive of the data values set. When investigating a country or countries taxation policies within the mining industry, nothing is rarely left to chance in the histology of data and its predictive anomalies, therefore future mining contracts, durations, extraction tonnage volumes, and revenues acquired chronologically were collated via MMHI, (2017), Mongolian Ministry of Mining and Heavy Industry. Finally, research into Kazakh jurisdiction mandates was reviewed within the question "Does any legislation provide for tax stabilization or are there tax stabilization agreements in force?" Jurisdiction, (2017), Mining. Kazakhstan. 
In conclusion, this literature review was to highlight the sources where data was extracted and to retain both unambiguity and objectiveness within this paper's content and its academic conclusions.

According to the Mongolia Country Commercial Guide (2018) 'Two mega-projects represent the promise of Mongolia's mining sector: the Oyu Tolgoi copper-gold project (OT) and the Tavan Tolgoi coking coal project (TT). The OT mine alone contains over 35 million tons of copper and 1,275 tons of gold and will likely drive Mongolia's GDP growth for at least the next three decades. At full capacity, OT will produce 450,000 tons of copper a year, close to three percent of world output. Production at OT started in 2013 and is projected to reach full capacity by 2025 . OT's $\$ 7$ billion development of its underground operations will offer ongoing procurement opportunities during the 2017-2022 build-up and for the life of the mine'. That being said, it remains to be unclear that Mongolia is benefitting financially from its mining activities. The aim of this study was to, therefore, arrive at some coherence pertaining why are there two paces of infrastructure development within both neighbouring countries even though they share similar demographics and Mining activity; where two notable conglomerates operate in both Kazakhstan and Southern Mongolia.

\section{Method}

The premise of this investigation was to uncover how much a developing nation's capital city could be affected in light of ineffective revenue collection or external forces intervention on controlling both a country's welfare and its eventual development. In addition, the very same multinational companies operating in the very same said nations, have been scrutinized qualitatively and quantitatively throughout. This body of research over a two-year cycle investigated 12 major Minerals and Metals that are currently being mined in Mongolia's South Gobi region were chosen as samples for this paper. Moreover, Copper Concentrate was selected as a taxation comparison barometer to ascertain the deviation between the Kazakh Government and the Mongolian Treasury. In addition, the data will also show the actual stakes in the mining fields for each of the two nations cited.

Data collection was obtained and correlated from sources primarily of the Netherlands, Mongolia, Vancouver, and Luxembourg. Statistics were gathered from National Statistics of Mongolia and the latest data from Deloitte pertaining to the New Taxation Rates on mining sales inclusive of coal for Kazakhstan with projections from 2018 to 2022.

\section{Delimitations}

The parameters within this research were to merely use the data, which has already been defined, in the public gaze and still within the framework of national debate, however:

a) Data which has not been included, are citations pertaining to in rhetorical nature that is still been litigated within both national and international jurisprudence guidelines. Thus, this aforementioned literature will not be included in any statistical nature of this draft.

b) The main aim of the data used is a comparative of a two-nation taxation policy within the difference, simply put; an analysis of why there are two countries of similar demography and mine near identical commodities inclusive of minerals and precious metals, have entirely varying taxation policy to acquire revenue for their respective exchequers?

c) The procedures and methods that have not been undertaken are elements such as statistical questionnaires and direct scholastic/journalistic inquiry via face-to-face interviews (Direct Engagement). This is attributed to both the political and legal sensitivities of the issues portrayed in this study inclusive of the author's geographical residency.

\section{Results and Discussion}

\section{Quantitative}

The data represented below indicates the issues that Mongolia faces with regard to stakeholder controls within the South Gobi mining sites with respect to mining multinationals. $34 \%$ of a stake in an extraction project within its own territory, does not constitute a revenue-healthy environment which is illustrated in both Figures 1 and 2 below (Kiezebrink, V. et al., 2018). 


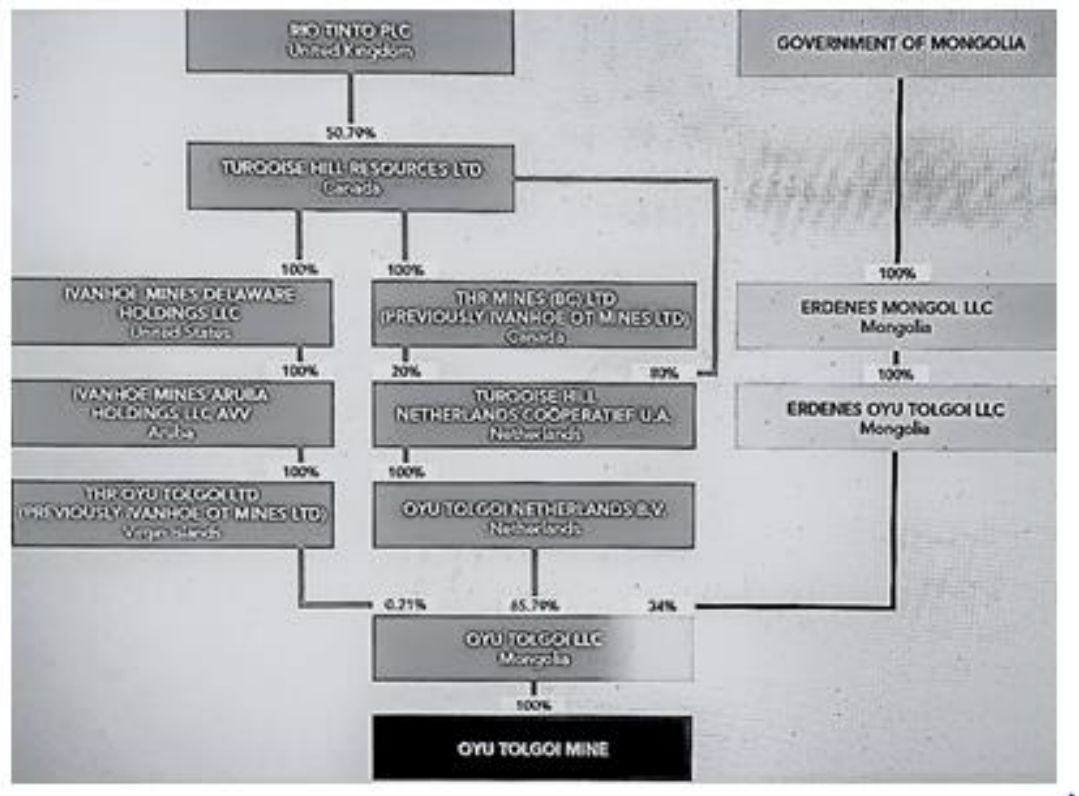

Figure 1. Stakeholders Control Summarization of Mines in Mongolia

Source: Ownership Structure OT, SOMO. OT (2018)

\section{OVERALL MINING STAKE CONTROL MONGOLIA}

- Mongolian Government $=$ Multinationals

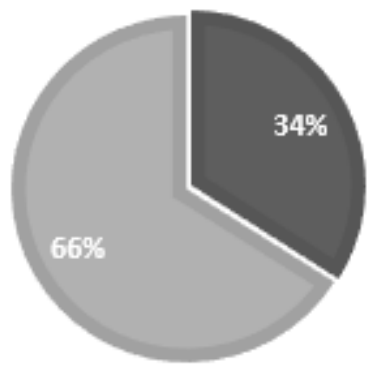

\section{OVERALL MINING STAKE CONTROL KAZAKHSTAN}

- Kazakhstan Gov. Multinationals

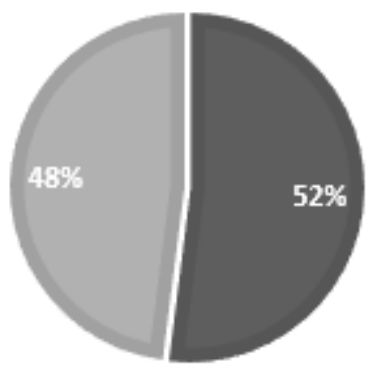

Figure 2. Overall Stake Controls: Mongolia vs Kazakhstan

Source: SOMO data 2018 contrasted with Kazakhstan's data via Deloitte Tax alert Kz \& Kazatomprom's influence: Bloomberg (2019) Kiezebrink, V. et al., (2018)

The key issue for extrapolation is that the data notated above clearly highlights the differences in national protection of resources clearly defined with the lesser stake supervised by Mongolia. However, Kazakhstan since embarking into major extraction of its minerals under Soviet legislation, it has maintained a stringent legal policy on tendering to multinationals. It has completely controlled MET (Mining Extraction Taxes) payable on the valuable resources produced, and payable on a quarterly basis. The average exchange is determined via the Precious Metals Exchange in London. Moreover, additional payment is incurred: Subsoil rental (over 60 Months) No special tax advantages are available to companies carrying out mining activities in Kazakhstan. Hence, the OECD are vying to convince the government to follow an international taxation policy on extraction levies. Therefore, lowing the revenue for the Kazakh treasury and in turn increasing multinational companies' profitability.

Mongolia's future is promising according to the Mongolian Ministry of Mining and Heavy Industry (MMHI). For example, their data suggests that following as stated: Two mega-projects represent the promise of Mongolia's mining sector: the Oyu Tolgoi copper-gold project (OT) and the Tavan Tolgoi coking coal project (TT). The OT mine alone contains over 35 million tons of copper and 1,275 tons of gold and will likely drive Mongolia's GDP growth for at least the next three decades. At full capacity, OT will produce 450,000 tons of copper a year, close to three percent of world output. Production at OT was initiated in 2013 and is projected to reach full capacity by 2025 . OT's $\$ 7$ billion development of its underground operations will offer ongoing 
procurement opportunities during the 2017-2022 build-up and for the life of the mine (MMHI, 2017). However, we must see a change within Mongolia's MET to at a minimum levied to $40 \%$ from the windfall tax which is unfortunately in place now. Exemplifying the current status of taxes levied in Kazakhstan on mining companies on the extraction of its natural resources.

Table 1. Comparison in Sales Taxation on Extracted Resources between Nations 2018-2022

\begin{tabular}{|c|c|c|c|c|c|}
\hline Country & Year & Tax Levied & Country & Year & Tax Levied \\
\hline Kazakhstan & Jan 2018 & $35 \%$ & Mongolia & Jan 2018 & Windfall $(\mathrm{Cu})$ \\
\hline & Jan 2019 & $40 \%$ & & Jan 2019 & Windfall $(\mathrm{Cu})$ \\
\hline & Jan 2020 & $50 \%$ & & Jan 2020 & Windfall $(\mathrm{Cu})$ \\
\hline & Jan 2022 & $40 \%$ & & Jan 2022 & Windfall $(\mathrm{Cu})$ \\
\hline
\end{tabular}

Source: SOMO and OT Watch Vincent Kiezebrink \& Rhodante Ahlers \& Sukhgerel Dugersuren (2018)

"Law on Taxes and Other Obligatory State Budget Payments (the "New Tax Code") was developed within the framework of the government's response to the President's "Kazakhstan in the New Global Reality: Growth, Reforms and Development" message and the "100 Concrete Steps" Plan of the Nation to realize five institutional reforms. On 25 December 2017, the President of the Republic of Kazakhstan had signed and enacted the New Tax Code" (Deloitte, 2018). Conversely, in Mongolia, the data below denotes the twelve chosen minerals in this study extracted in Mongolian in 2017 in Figures 3, 4, 5 and 6, as coherent quantitative indicators.

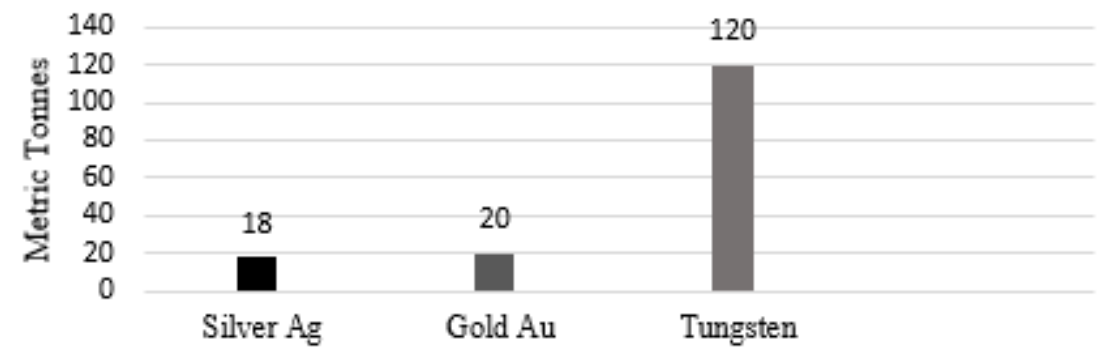

Figure 3. Metals Extracted from Mongolian Land 2017

Source: TradingEconomics.com 2017 Oil Production, (Spot)
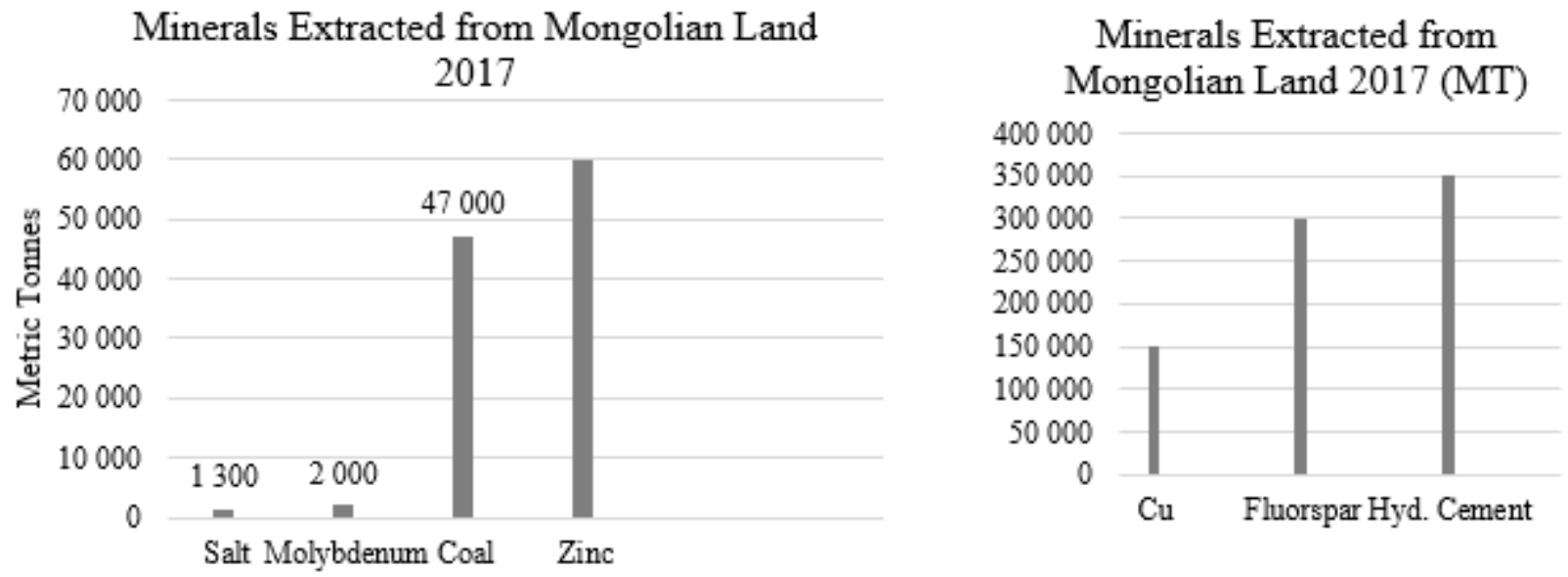

Figures 4-5. Other Minerals as part of Sampling

Source: Ministry of Mining and Heavy Industry (MMHI) - Montsame Report. Batchimeg, B. (2017)

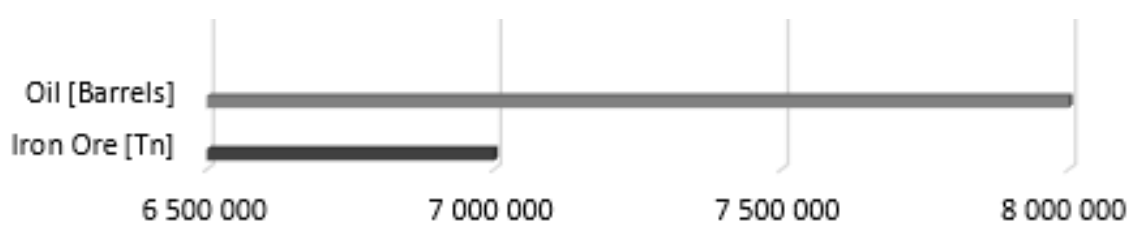

Figure 6. Oil and Iron Extraction Mongolia 2017

Source: TradingEconomics.com 2017 Oil/Fe Production, (Spot) 
Table 2. Total Extraction of 12 Sample Minerals Resources from Mongolian Land in 2017

\begin{tabular}{|l|c|c|c|c|}
\hline $\begin{array}{c}\text { Materials } \\
\text { Extracted }\end{array}$ & $\begin{array}{c}\text { Quantities Extracted } \\
\text { Units: MT } \\
\text { \& Barrels }\end{array}$ & $\begin{array}{c}\text { Market Prices (US \$) } \\
\text { Dated: 05/Oct/2018 }\end{array}$ & $\begin{array}{c}\text { NET Revenue from } \\
\text { Exports of Proposed } \\
\text { Mining Companies (US \$) }\end{array}$ & $\begin{array}{c}\text { Flat Profit at 40\% } \\
\text { Taxable } \\
\text { Mevenue for } \\
\text { Mongolian Treasury \$ }\end{array}$ \\
\hline Silver & 18 & $1,000,000 / \mathrm{Mt}$ & $18,000,000.00$ & $7,200,000.00$ \\
\hline Gold & 20 & $38,000,000 / \mathrm{Mt}$ & $760,000,000.00$ & $304,000,000.00$ \\
\hline Tungsten & 120 & $430 / \mathrm{Mt}$ & $51,600.00$ & $26,640.00$ \\
\hline Salt & 1,300 & $35 / \mathrm{Mt}$ & $45,500.00$ & $2,080,000.00$ \\
\hline Molybdenum & 2,000 & $26,000 / \mathrm{Mt}$ & $5,200,000.00$ & $1,128,000.00$ \\
\hline Coal & 47,000 & $60 / \mathrm{Mt}$ & $2,820,000.00$ & $80,880,000.00$ \\
\hline Zinc & 60,000 & $3,370 / \mathrm{Mt}$ & $202,200,000.00$ & $375,720,000.00$ \\
\hline Copper & 150,000 & $6,262 / \mathrm{Mt}$ & $939,300,000.00$ & $52,800,000.00$ \\
\hline Fluorspar & 300,000 & $\approx 440 / \mathrm{Mt}$ & $132,000,000.00$ & $7,800,000.00$ \\
\hline Hyd. Cement & 350,000 & $\approx 57 / \mathrm{Mt}$ & $19,950,000.00$ & $193,200,000.00$ \\
\hline Iron Ore & $7,000,000$ & $69 / \mathrm{Mt}$ & $483,000,000.00$ & $236,800,000.00$ \\
\hline Crude Oil & $8,000,000$ & $74 / \mathrm{bbl}$ & $592,000,000.00$ & $\mathbf{1 , 2 6 2 , 8 2 6 , 8 4 0 . 0 0}$ \\
\hline & & TOTAL & $3,154,567,100.00$ & \\
\hline
\end{tabular}

$\underline{\text { Key: }}{ }^{\approx}=$ Approximately; Mt $=$ Metric Tons; bbl. = Barrels

Source: TradingEconomics.com 2017 Oil Production, Index Mundi Pricing (Spot)

This is a mere sampling of 12 minerals calculated at the US \$ rate at 3 October 2018. Consequently, Net revenue: $\$ 1,262,826,840.00 *$ (5-year period) $=\$ 6,314,134,200.00$ net taxation revenue for the Mongolia treasury. This is evidence enough that the Government of Mongolia would have never required a $\$ 434$ million IMF loan over three years nor the $\$ 5.5$ billion finance package (Tranche-Based) if they were to have in place a Mining Extraction/Sales Profit Taxation system for all the multinational companies. a) The data speaks volumes. Especially menacing for Ulaanbaatar is that this finance package is supported by Japan, Korea, China, the World Bank, and the Asian Development Bank. This was not good fiscal news for the Mongolian treasury; this loan has assigned them to being control via debt. Globalist bankers have loaned monies to vulnerable countries to acquire control over their sovereignty, and it has been exemplified here. Therefore, all inspections of the Mongolian banking system, Taxation Models and Budgeting will be under the governance of the IMF. Subsequently, Mongolia raised income taxes on its small population in January 2018. b) If we were to view Table 3, the populations between both Mongolia and Kazakhstan, we would see a marked difference between them. Instead of self-reliance on income tax rises upon its population, Mongolia ought to have tax levied the Multinationals on sales from its own extracted natural resources from its own land.

\section{Qualitative}

Table 3. Populations-Working by Country at 2018

\begin{tabular}{|c|c|c|}
\hline Country & Population & Working Population \\
\hline Kazakhstan & $18,556,698$ & {$[68 \%] 12,618,554$} \\
\hline Mongolia & $* 3,100,000$ & $\begin{array}{ll}61 \%] & 1,891,000\end{array}$ \\
\hline
\end{tabular}

Source: Mongolian National Statistics Office 2018

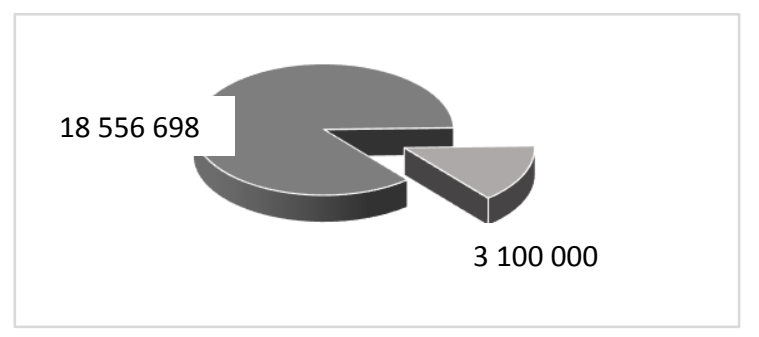

Figure 7. Populous Comparative

Source: Mongolian National Statistics Office 2018

With an advantage of 10,727,554 in working population, from the data, Kazakhstan's ability to fill its treasury coffers could be obtained in two significant ways; with its strengthened availability of income taxation levied upon its citizens and secondly from the fixed-rate tax sales-profit policy onto the mining multinationals. c) Quantitative results depict a wide income disparity gulf between these two sample nations. d) The aforementioned can be illustrated in the physical geopolitical differences in Astana (Kazakh Language for capital city) to Ulaanbaatar (Mongolia's capital city) Astana was named the capital of Kazakhstan in 1997 and 
ISSN (online) - 2520-6311; ISSN (print) - 2520-6761

has undergone a massive transformation since then. The city is filled with futuristic skyscrapers that resemble a science-fiction movie. Abadi, M. (2018). e) In comparison, Ulaanbaatar (UB) is still seeking the investment required to replicate Astana's astonishing growth. Ulaanbaatar dates to 1639 built originally for 400,000 inhabitants, now has three times this number. In fact, it reached that number by 1979. Since then, it has tripled that figure. However, its needed development and expansion has been laborious, due to lack of investment and foresight or vision. It is very much the poorer cousin of Astana and terribly polluted. From the results collated with correlation, it is evident that the deficit of revenue received in taxation has contributed to the many issues that lay in Ulaanbaatar. Consequently, the Mongolian government can only increase income tax onto its people rather than levying the mining multinationals; who have indeed had a sixty-six-percentile advantage in stake holding. f) Astana's workforce receives 51\% higher salary band than those of Ulaanbaatar. Deloitte. (2018) Japanese architects were tasked to build this modern city with affordable housing, however education within Mongolia's entrepreneurship needs revisiting, as many private construction companies in Ulaanbaatar have sprung-up building upmarket modern apartments that remain unoccupied due to lack of economic mass population's unaffordability, thus lack of research prior to a building project being conceived. Taking this aforementioned data into consideration, it is very much a tale of two cities. The counter-argument from Mongolia is that the mines are still developing and no major taxation ought to be levied. However, Mining operations have been online for a considerable time.

Currently, as the cumulative data illustrates that Mongolian Copper extracted from the Southern Gobi Area is the only commodity that is indeed subjected to any form of taxation. Therefore, if we refer to Table 4 below, which has been modified from Table 2 negating the final column for the proposed $40 \%$ mining taxation on sales on exports entitled “Flat Profit at 40\% Taxable Revenue for Mongolian Treasury \$”, then we could calculate the statistical differentiation via the model Standard Error of the Difference, to highlight the differences in Mongolia's taxation policy Compared to Kazakhstan.

Table 4. Extraction figures published in 2017 with Windfall Taxation and Ambiguous Rates at 10\%

\begin{tabular}{|c|c|c|c|c|}
\hline \multicolumn{5}{|c|}{ Total Extraction of 12 Sample Minerals Resources from Mongolian Land in 2017} \\
\hline $\begin{array}{l}\text { Materials } \\
\text { Extracted }\end{array}$ & $\begin{array}{c}\text { Quantities Extracted } \\
\text { Units: MT } \\
\text { \& Barrels } \\
\end{array}$ & $\begin{array}{c}\text { Market Prices (US } \\
\text { \$) Dated: } \\
\text { 05/Oct/2018 }\end{array}$ & $\begin{array}{c}\text { Gross Revenue from } \\
\text { Exports of Proposed } \\
\text { Mining Companies (US \$) }\end{array}$ & $\begin{array}{c}\text { Flat Profit at Windfall } \\
\text { Tax Revenue for } \\
\text { Mongolian Treasury \$ }\end{array}$ \\
\hline Silver & 18 & $1,000,000 / \mathrm{Mt}$ & $18,000,000.00$ & None Specified or $10 \%$ \\
\hline Gold & 20 & $38,000,000 / \mathrm{Mt}$ & $760,000,000.00$ & None Specified \\
\hline Tungsten & 120 & $430 / \mathrm{Mt}$ & $51,600.00$ & None Specified \\
\hline Salt & 1,300 & $35 / \mathrm{Mt}$ & $45,500.00$ & None Specified \\
\hline Molybdenum & 2,000 & $26,000 / \mathrm{Mt}$ & $5,200,000.00$ & None Specified \\
\hline Coal & 47,000 & $60 / \mathrm{Mt}$ & $2,820,000.00$ & None Specified \\
\hline Zinc & 60,000 & $3,370 / \mathrm{Mt}$ & $202,200,000.00$ & None Specified \\
\hline Copper & 150,000 & $6,262 / \mathrm{Mt}$ & $939,300,000.00$ & $375,720,000.00$ \\
\hline Fluorspar & 300,000 & $\approx 440 / \mathrm{Mt}$ & $132,000,000.00$ & None Specified \\
\hline Hyd. Cement & 350,000 & $\approx 57 / \mathrm{Mt}$ & $19,950,000.00$ & None Specified \\
\hline Iron Ore & $7,000,000$ & 69/Mt & $483,000,000.00$ & None Specified \\
\hline Crude Oil & $8,000,000$ & $74 / \mathrm{bbl}$ & $592,000,000.00$ & None Specified \\
\hline & & TOTAL & $3,154,567,100.00$ & $375,720,000.00$ \\
\hline
\end{tabular}

Source: Commodity Prices - Compliments of Index Mundi - Dated: 05/10/2017 - Montsame Report MMHI Batchimeg, B. (2017)

At the time that this paper is published, all of the twelve cited commodities inclusive of minerals are being taxed differently on sales between these two nations - inclusive of policy.

This paper would have examined thus, determined correlated revenue differences for all 12 raw materials mined in both Kazakhstan and Mongolia to correlate this data empirically. As previously stated on p. 54 Table 1. Comparison in Sales Taxation on Extracted Resources between Nations 2018-2022. The Republic of Kazakhstan had signed and enacted the "New Tax Code" Deloitte, 2018. Referring to the p. 54 tabulation, this year 2019, all mining companies are being levied $40 \%$ on all resources extracted from their sovereign land, however, the Mongolian model remains unchanged or in fact, being levied at 10\%. If we were to use the 2018 taxation and Investment taxation levies inclusive of Royalties Ref: "Taxation and Investment in Mongolia" (Deloitte, 2018) i.e. Investment Tax $=10 \%$ and Royalties $=10 \%$, thus, it is suggested the total $20 \%$ levies could be imposed upon these mining companies to create income for the Mongolian Treasury. 
Table 5. Raw Data from Potential Revenue if Kazakhstan's Flat Rates were in Mongolia?

\begin{tabular}{|l|c|c|c|}
\hline $\begin{array}{c}\text { Resourced } \\
\text { Materials } \\
\text { Extracted }\end{array}$ & $\begin{array}{c}\text { Gross Revenue from Exports } \\
\text { of Proposed Mining } \\
\text { Companies (US\$) }\end{array}$ & $\begin{array}{c}\text { Kazakhstan 40\% Fixed Flat } \\
\text { Rate if Levied on Mongolia's } \\
\text { Mining Company Revenues = } \\
\text { Net Revenue for 2018 (US\$) }\end{array}$ & $\begin{array}{c}\text { Mongolia without fixed flat } \\
\text { Taxation Levies. If Royalties and } \\
\text { Resident Taxpayers totals 20\% } \\
\text { were to be introduced = Net } \\
\text { Revenue for 2018 (US\$) }\end{array}$ \\
\hline Silver & $18,000,000.00$ & $7,200,000.00$ & $3,600,000.00$ \\
\hline Gold & $760,000,000.00$ & $304,000,000.00$ & $60,800,000.00$ \\
\hline Tungsten & $51,600.00$ & $20,640.00$ & $10,320.00$ \\
\hline Salt & $45,500.00$ & $18,200.00$ & $9,100.00$ \\
\hline Molybdenum & $5,200,000.00$ & $2,080,000.00$ & $1,040,000.00$ \\
\hline Coal & $2,820,000.00$ & $1,128,000.00$ & $564,000.00$ \\
\hline Zinc & $202,200,000.00$ & $80,880,000.00$ & $40,440,000.00$ \\
\hline Copper & $939,300,000.00$ & $375,720,000.00$ & $26,400,000.00$ \\
\hline Fluorspar & $132,000,000.00$ & $52,800,000.00$ & $3,990,000.00$ \\
\hline Hyd. Cement & $19,950,000.00$ & $7,980,000.00$ & $96,600,000.00$ \\
\hline Iron Ore & $483,000,000.00$ & $193,200.000 .00$ & $118,400,000.00$ \\
\hline Crude Oil & $592,000,000.00$ & $236,800,000.00$ & $\mathbf{\$ 5 3 9 , 7 1 3 , 4 2 0 . 0 0}$ \\
\hline & $\mathbf{\$ 3 , 1 5 4 , 5 6 7 , 1 0 0 . 0 0}$ & $\mathbf{\$ 1 , 2 6 1 , 8 2 6 , 8 4 0 . 0 0}$ & \\
\hline
\end{tabular}

Source: Calculated via Commodity Pricing from Index Mundi - Market Pricing Dated: 05/10/2017

Table 5 illustrates, if the Mongolian Policy-makers were to introduce the basic levies imposed onto the foreign mining entities it would easily finance its affairs of state as Kazakhstan once achieved with the rebuilding of Astana with limited pollution and to raise salaries for its working population. Higher income ratios have led to sustainable treasury income. In 2019, there has been little improvement to Mongolia's Mining taxation state of affairs. Referring to the data, it is clear or unambiguous to see that even at $20 \%$ from a combination from Royalties and Investment levies, annual income for the Mongolian treasury could have accumulated to $\$ 539,713,420.00$ in net revenue.

\section{Scientific Discussion}

Given a statistical property known as the central limit theorem, we know that, regardless the distribution of the parameter in the population, the distribution of these means, referred as the sampling distribution, approaches a normal distribution with mean and standard deviation confuse the standard deviation and the standard error, possibly because the names are similar, or because the standard deviation is used in the calculation of the standard error. However, they are not quite the same, and it is important that readers (and researchers) know the difference between the two so as to use them appropriately and report them correctly. Biau, J., 2011. Therefore, SEM-SD was used for the arithmetic tool within the following process.

\section{(SEM) - (SD) Standard Error of the Difference in Revenue Acquired via Mining Taxation}

$S E D=\sqrt{S E 1^{2}+S E 2^{2}}$

$S E m=\frac{S D}{\sqrt{N-1}}$

$S D=\frac{\sqrt{\sum_{X} 2}}{N}$

The sum of all data is calculated on Net Revenues if Mongolia adopted the Kazakh fixed-rate model of sales taxation. The suggested Mongolian fixed-rate combination of Royalties and Investment levies at 20\% is calculated to the 40 percentiles currently in place in Kazakhstan. Therefore, the results of the Standard Error of the Difference are from the raw data acquired from Table 4's last two columns to the right. The control grouping is divided in .Kz (Kazakhstan) as the control model and .Mn (Mongolia) the proposed experimental group. The unit of measure is defined as per million $\$$ in target revenue base. 


\section{Largest Resources Calculated at the Two Rates}

Kz. 40\% Mining Tax Rate Mn. 20\% Mining Tax Rate

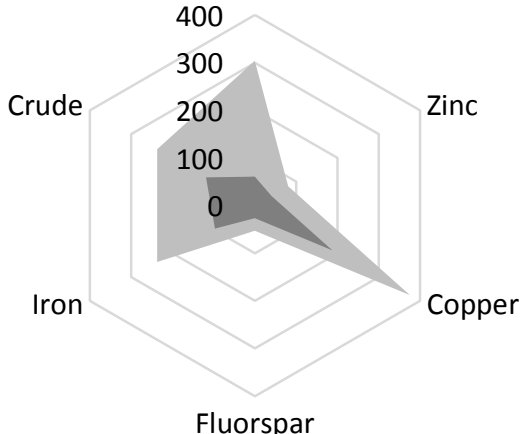

Figure 8. Major Resources Mined with Revenues Calculated at 20\%/40\% Unit Per Million USD \$ Source: SOMO and OT Watch Kiezebrink, V. et al. (2008) p. 17, and Biau, J. (2011) Standard Error

Table 6. Value $(\mathrm{n}=12)$ Commodities + Revenue $\sum_{X} 2$ Tabulation Unit (Per Million $\$$ )

\begin{tabular}{|l|c|c|c|c|}
\hline \multicolumn{1}{|c|}{ Resources } & $\mathbf{. K z} \mathbf{4 0 \%}$ Tax Model & $\sum_{\boldsymbol{X}} \mathbf{2}$ & $\mathbf{. M n}$ Tax Model 20\% & $\sum_{\boldsymbol{X}} \mathbf{2}$ \\
\hline Silver & & 51.9 & 3.6 & 13.0 \\
\hline Gold & 7.2 & 92416.0 & 60.8 & 3697.0 \\
\hline Tungsten & 04.0 & 0.0004 & 0.010 & 0.001 \\
\hline Salt & 0.018 & 0.0003 & 0.009 & 0.000018 \\
\hline Molybdenum & 2.8 & 7.8 & 1.04 & 0.08 \\
\hline Coal & 1.2 & 9.4 & 40.4 & 1632.2 \\
\hline Zinc & 80.9 & 6545.0 & 187.9 & 35306.0 \\
\hline Copper & 375.7 & 140625.0 & 26.4 & 697.0 \\
\hline Fluorspar & 52.8 & 2788.0 & 4.0 & 16.0 \\
\hline Hyd. Cement & 7.9 & 62.4 & 96.6 & 9322.0 \\
\hline Iron Ore & 193.2 & 37326.0 & 118.4 & 14019.0 \\
\hline Crude Oil & 236.8 & 56074.0 & $\mathbf{5 4 0 . 0}$ & $\mathbf{6 4 7 1 4 . 0}$ \\
\hline Totals for $\boldsymbol{N =}$ & $\mathbf{1 2 6 3 . 0}$ & $\mathbf{3 3 5 9 0 5 . 5}$ & & \\
\hline
\end{tabular}

$\mathrm{N}=$ Number in Study: $\mathrm{n}=12$

Source: Experimental Group.Mn vs Control Group.Kz - (20\% \& 40\%) Standard Deviation and Standard Error. Biau, J. (2011)

\section{Arithmetic's for Standard Error of the Difference: Kz (Kazakhstan) Mn (Mongolia)}

$K z: M_{1}=\frac{\sum x}{n}=\frac{1263}{12}=105.25 \quad M n: M_{2}=\frac{\sum x}{n}=\frac{540}{12}=45.0$

$K z: \mathrm{SD}=\frac{\sqrt{\sum_{X} 2}}{N}-M^{2}=\frac{\sqrt{335905.5}}{12}-105.25^{2}=27992.12-11077.6=\sqrt{16914.50}==130.06$

$M n: \mathrm{SD}=\frac{\sqrt{\sum_{X} 2}}{N}-M^{2}=\frac{\sqrt{64714}}{12}-45^{2}=5392.83-2025.00=\sqrt{3367.83}=58.03$

The data correlated SD when Mongolia is correlated to Kazakhstan then $S D=\frac{58.03}{130.06}=0.45$

$K z: \quad S E m=\frac{S D}{\sqrt{N-1}}=\frac{130.06}{\sqrt{12-1}}=\frac{130.06}{\sqrt{11}}=\frac{130.06}{3.317}=39.21$

$M n: \quad S E m=\frac{S D}{\sqrt{N-1}}=\frac{58.03}{\sqrt{12-1}}=\frac{58.03}{\sqrt{11}}=\frac{58.03}{3.317}=17.50$

The data correlated within the error; Mongolia is correlated to Kazakhstan then $S E m=\frac{17.50}{39.21}=0.45$ Resulting data recorded above clearly illustrates that if Mongolia were to implement credible mining taxation policy then it could redevelop the country via self-financing from revenue obtained at the treasury. 


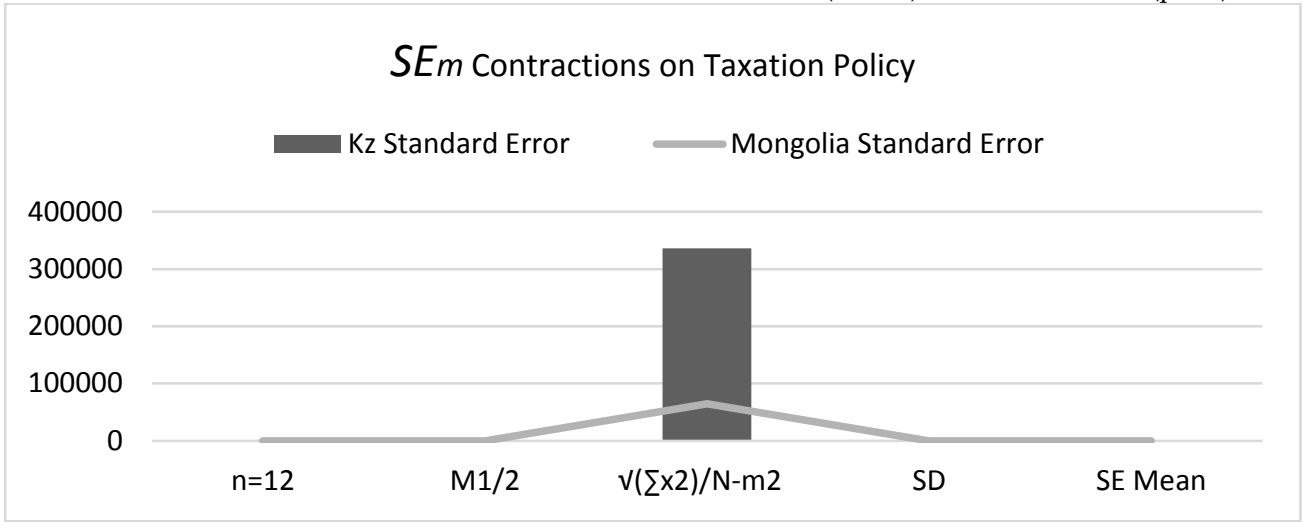

Figure 9. Standard Error Contraction only when revenue Mean increases 2018

Source: Standard Deviation and Standard Error. Biau, J. (2011) Bell Curved

Only upon which the data trail exceeds the revenue of Mongolia by Kazakhstan it is evident that the deviation occurs as Mongolia's taxation remit does not match the clear flat-rate tools of levied to the mining companies operating within its borders. Individual commodity sales taxation below $\$ 100,000,000$ of annual revenue for Mongolian production will suffer as mining increases, as there is no present mechanism for corporation taxation throughout its resources. Even a suggested 20\% flat tax denominator could assist their treasury, however, there is not any fiscal stability for future operations, as the foreign mining companies' operations in Mongolia, have prospered further by via tax avoidance. Thus, Kazakhstan's taxation policies have a vast advantage over its geographical neighbour.

\section{Conclusion and Discussion}

It is evident from the findings within this document that the multinationals have indeed opened a gateway via the initial tendering negotiations, to merely promise the MMHI employment for its citizens with liveable salaries, rather than being taxed according to Kazakh flat rate method which is indeed levied upon companies there. Therefore, the Mongolian treasury has not received its deserved revenue from the extraction of its national resources, hence its balance sheet is rather bereft of funding to continue the development of its Capital City and other parts of its country. The result eventually, was a gateway being opened for the IMF and World Bank to initiate external financing for the Mongolian Exchequer, then country fiscal control is complete. In short, if the qualitative data is believed, Mongolia would not require external financing and would be deemed self-sufficient via its immense natural resources; inclusive of another one trillion US dollars beneath its own terra firma. The question is Mongolia has so many minerals, but where is the money?

If we sought the definition of Mining Taxation, we would re-visit September, 2011. As a consequence of public pressure for mining minerals and commodity reform, "The Purpose of Mining Tax was published in Mongolia. It stated: While compulsory payments such as "royalties" paid for the right to extract and sell mineral resources are often labelled a "tax", from a design point of view, it is more useful to recognize their economic function rather than their legal form. A mining tax is simply the price charged by a country for the sale of mineral resources that belong to the country. The owner of the resource (Mongolia in this case) sells it to an intermediary (the mining company) that in turn sells it to customers who use the resource to make various types of metals or who use it in their business (for example, burning coal). In return for a payment, the country sells the resource to a mining company and, because the resource it is selling lies beneath the surface of the ground, also gives the mining company the right to extract the resource it is buying. The mining tax that is in effect the selling price for minerals is quite different from the profits tax (the company income tax) that is imposed on all businesses. The ideal company income tax applies in a similar fashion to all companies so it does not distort economic behaviour by changing the after-tax rate of return for some sectors compared to others. So long as all profits are taxed similarly, ordinary market forces will lead investors to decide which businesses should be supported and the economy will enjoy the most efficient allocation of foreign and domestic capital Kerver. (2011).

One could imagine the possibilities that could be availed to Mongolia and its capital city Ulaanbaatar. Education would be transformed; its infrastructure could be redefined alike Astana and pollution would be eradicated forever via new affordable state dwellings for the suburban "Ger" district. This would in-affect improve air quality by $70 \%$ for the whole city. Shirking responsibilities like education and medicine then outsourcing them to the private sector, has been proven to be an unaffordable policy for the masses and 
ISSN (online) - 2520-6311; ISSN (print) - 2520-6761

devolution for student development in the face of a spreadsheet's profitability unless you are a private language school trying to both educate and modernize a country's linguistic ability.

Copper remains the only Mongolian resource to be taxed corporately today. State control is key to its national resources. It is therefore recommended that a fixed rated taxation policy be adopted for the extraction of Mongolia's Natural Resources from 35\%-40\%. In addition, Royalties and Stakeholder control contracts overall ought to be re-visited and re-negotiated away from global banking control entities, thus reversing the current influence on Mongolia's leadership and economic policy inclusive strategic apparatus. Presently, cost overruns plague the Gobi Mining Site. If we were to believe the current taxation scandals, Mongolia is working with overseas investigators to look into claims of corruption at its giant Oyu Tolgoi copper mine, the country's antigraft body said on Tuesday, after the re-arrest of a former minister suspected of "abuse of power". Bayartsogt Sangajav was first arrested last April and released in June in a probe into 2009 negotiations over the development of the mine, then owned by Canada's Ivanhoe Mines and now managed by Anglo-Australian miner Rio Tinto. Bayartsogt, a former finance minister, was among the signatories to the investment agreement, approved by Mongolia's parliament (therefore, giving fiscal favoured alternatives to the mining companies in reference to taxation levies). Munkhtungalag Tumur, a spokeswoman with the country's Independent Authority Against Corruption (IAAC), had told Reuters it was conducting a thorough financial investigation into the allegations that would be international in scope. She did not identify with which other countries the IAAC was collaborating. The mine, run by Rio Tinto since 2010, is central to the firm's push to reduce its reliance on iron ore sales. But the miner has faced a series of wrangles with the Mongolian government over tax payments and cost overruns. Expansion plans will make Oyu Tolgoi, located near the southern border with China, one of the world's biggest copper mines early in the next decade (Munkhchimeg, D. and Lewis, B., 2019). Could this be the obvious reason for the lack of Mongolian Taxation Strategies or indeed the avoidance of renegotiating a fair deal for its treasury, thus improving their population's livelihood and well-being?

If we were to believe both the data predictions for 2020: Mongolia is a leading producer of coking coal, copper, iron ore, and crude oil, but exports nine minerals in total. Extractive industries accounted for $20 \%$ of GDP, $18.6 \%$ of government revenue and 86.2\% of total exports in 2016 according to the 2016 EITI Report. The Oyu Tolgoi copper and gold mine is the single largest mining project, which should account for a third of GDP from 2020. Tavan Tolgoi is the world's largest undeveloped coal mine. Then from this paper's findings with the consequential outcomes, Economists would deduce that the 2020 prediction cited above is beyond unrealistic.

According to Mining Journal a leading contributor for Mining News, "the 2009 agreement gave 34\% of the copper-gold project to the Mongolian government and 66\% to Ivanhoe Mines, now the Rio Tinto-controlled Turquoise Hill Resources. Turquoise Hill was hit with a US\$155 million bill from the Mongolian Tax Authority in January 2018 and the government cancelled a power agreement for the massive project the following month". It is clear with the accumulated data that Rio Tinto-controlled Turquoise Hill Resources was undertaxed with a $\$ 155 \mathrm{~m}$ invoice considering the profits made by this foreign miner. If we refer to Table 2 Copper on its own, extracted in the 2017 cycle $(6,000 \mathrm{MT})$ had a market value of $\$ 939,300,000.00$. Therefore, what would be the total revenue Net and consequently the amount sent to the Mongolia Exchequer? The number values do not correlate with the quantities mined.

The economic future for Mongolian Mining is promising, only if there were to be updated taxation legislation inclusive of legally controlled contract licensing. Furthermore, Kazakhstan has already established a tax levying system that caters for its own development funding, but also it has initiated mass reconstruction via Japanese contractors. If we were to analyze the mineral reserves below the Mongolian Southern Gobi, then one could envisage a prosperous future-referring to Table 7 overleaf:

Table 7. Top Mongolian Mineral Reserves Projection EITI Report 2016

\begin{tabular}{|l|c|l|}
\hline \multicolumn{1}{|c|}{ Commodities } & Reserves & \multicolumn{1}{c|}{ Unit of Measure } \\
\hline Oil & 2.4 & Billion Barrels \\
\hline Gold & 591,244 & Metric Tons \\
\hline Silver & 3,493 & Metric Tons \\
\hline Copper & 53.6 & Million Metric Tons \\
\hline Coal & 26.57 & Billion Tons \\
\hline Iron & 348.11 & Million Metric Tons \\
\hline
\end{tabular}

Source: EITI (2016) Reserve 
Finally, being reminded that thoughtless decisions of our historical/corporate past, and their unfortunate applications, had manifested into economic conflict subsequently destroying nations... Surely it is what we could do in guiding such civilizations that would, and indeed define us as an intelligent species and as notable research academics. These said academics must advise their governments on treasury stabilization of acquiring a deserved revenue, in line with Kazakh levels previously notated. From all the data of revenue and negative taxation policies in Mongolia that I respectfully disagree with the UNDP's findings in an editorial entitled "From Mineral Riches to A Sustainable Future". The figures researched in this paper are not conducive with a prosperous future for Mongolian Mining nor being sustainable for the future. The UNDP and UNESCAP as part of its Sustainment Development Goals stated: Parliament approved Mongolia's Sustainable Development Vision 2030 (SDV) translating the global goals into Mongolian context. The key to achieving the objectives articulated in Mongolia's SDV and the SDGs will be to ensure that the country can transform the growth potential from its vast mineral wealth into inclusive and environmentally sustainable development. Yet once again, mathematically with empirical consent, the above indicators, do not correlate within research computation. Sustainability of a nation fiscally is dependent on that country's Exchequer's ability to gain monies via rigid flat-rate taxation levies both being introduced and applied to these aforementioned foreign and national mining entities. Subsequently, 2030 was an unfortunate cited prediction by the United Nations.

\section{List of abbreviations}

MET - Mining Export Tax;

EITI - International Extractive Industries Transparency Initiative;

MMHI - Mongolian Ministry of Mining \& Heavy Industry;

OT - Oyu Tolgoi: Mongolian copper mining company;

TT - Tavan Tolgoi: Mongolian coal mining company.

\section{References}

1. Abadi, M. (2018). Inside the eerily quiet streets of Kazakhstan's 20-year-old capital city, where futuristic skyscrapers tower over the grasslands of a former prison camp. Business Insider. https://www.businessinsider.com/astana-kazakhstan-planned-city-2018-6. Business Insider (Accessed on 6 October 2016).

2. Anderson, J. H., Lee, Y. and Murrell, P. (2000). Competition and Privatization amidst Weak Institutions: Evidence from Mongolia. Economic Inquiry, 38(4), 527-549.

3. Auty, R. and Soysa, I. (2006). Energy, Wealth and Governance in the Caucasus and Central Asia: Lessons not Learned (Abingdon: Routledge).

4. Batchimeg, B. (2017). Mongolia exports 33.320.3 thousand tons of coal in 2017. MMHI: 2018-01-11 Press Conference. Available at: https://www.montsame.mn/en/read/133072 (Accessed 24 June, 2018).

5. Bedeski, R. (2006). Mongolia as a Modern Sovereign Nation-State. The Mongolian Journal of International Affairs, 13, 84.

6. Biau, J. (2011). In Brief: Standard Deviation and Standard Error Orthop Relat Res. 2011 Sep; 469(9), 26612664. doi: 10.1007/s11999-011-1908-9. PMCID: PMC3148365.

7. Bloomberg. KAO:LI (2019) Bloomberg Stock Watch. NAC Kazatomprom JSC Uranium. https://www.bloomberg.com/quote/INDU:IND?in_source=topQuotes. (Accessed 24/05.2019).

8. Bridge, G. (2004). Mapping the Bonanza: Geographies of Mining Investment in an Era of Neoliberal Reform. The Professional Geographer, 56(3), 406-421.

9. Campi, A. (2012). Mongolia's Quest to Balance Human Development in its Booming Mineral-Based Economy. Brookings Northeast Asia Commentary, 51. Available at: http://www.brookings.edu/research/opinions/2012/01/10-mongolia-campi (Accessed 29/08/2013).

10. Deloitte (2018). Introduction of the New Tax Code. Report for Kazakhstan. Available at: https://www2.deloitte.com/content/dam/Deloitte/kz/Documents/tax/TaxAlerts/Tax_Alert_January_2018.p df (Accessed on February 2018).

11.Deutsch, A. and Edwards, T. (2013). Special Report: In Tax Case, Mongolia is the Mouse that Roared. Reuters 16th July 2013. Available at: http://www.reuters.com/article/2013/07/16/us-dutch-mongolia-taxidUSBRE96F0B620130716 (Accessed 1/08/2013).

12.EITI Report (2019). Overview Mongolia. Available at: https://eiti.org/mongolia (Accessed 12 June 2018).

13.Export.gov. (2017). Mongolia-Mining. Available at: https://www.export.gov/article?id=Mongolia-Mining. (Accessed on 2 October 2018). 
Business Ethics and Leadership, Volume 3, Issue 2, 2019

ISSN (online) - 2520-6311; ISSN (print) - 2520-6761

14.Grant, M. (1959). The Annals of Imperial Rome by Tacitus. Mass Market Paperback, L60, (464 Pages). Published by Penguin Classics; Original Title Latin - Ab excessu divi Augusti.

15.Index Mundi (2018). Commodity prices. Available at: https://www.indexmundi.com/commodities/ (Accessed on 26 January 2018) (51).

16.Jurisdiction
https:/gettingthedealthrough.com/area/22/jurisdiction/62/mining-2017-kazakhstan/\#link-37. (Accessed June 2017).

17.KazWorld (2017). UK Considers Funding Mining Projects in Kazakhstan. Available at: $\mathrm{http}: / /$ kazworld.info/?p=62621 (Accessed on 26 January 2018).

18.Kerver, ILTOD Trade and Development (2011). Mining Tax and VAT Reform in Mongolia. Available at: https://www.iltod.gov.mn/?p=2085 (Accessed 21 March 2017).

19.Kiezebrink, V. et al. (2018). Mining taxes, "The case of Oyu Tolgoi and profitable tax avoidance by Rio Tinto in Mongolia” SOMO. (Accessed on 2 October 2018).

20.Mining Journal (2019). Mongolian Push for Oyu Tolgoi Deal Changes. Available at: https://www.miningjournal.com/politics/news/1360458/mongolian-push-for-oyu-tolgoi-deal-changes (Accessed 20 April 2019).

21.MMHI (2017). Mongolian Ministry of Mining and Heavy Industry. Mongolia Country Commercial Guide: gov/article?id=Mongolia-Mining (Accessed 2 October 2018).

22.Munkhchimeg, D. and Lewis, B. (2019). Reuters. Mongolia, overseas investigators probe Oyu Tolgoi corruption claims as ex-minister re-arrested. Available at: https://www.reuters.com/article/us-miningriotinto-mongolia/mongolia-overseas-investigators-probe-oyu-tolgoi-corruption-claims-as-ex-minister-rearrested-idUSKCN1PNOOY (Accessed 4 February 2019).

23.Trading Economics (2017). Oil Commodity Prices: https://tradingeconomics.com/mongolia/crude-oilproduction?poll=2018-04-30. (Accessed 23 May, 2018).

24.Trankmann, B. (2018). From Mineral Riches to a Sustainable Future. Available at: www.mn.undp.org/content/mongolia/en/home/blog/2018/from-mineral-riches--to-a-sustainablefuture.html (Accessed 27 April 2019). 